Indexed by

\title{
Scopus
}

\section{APPLICATION OF GEOELECTRICAL METHODS FOR IDENTIFICATION OF SOIL LAYER}
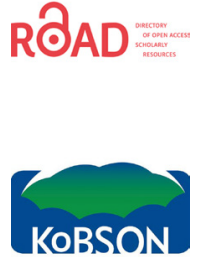

google
Devi Oktaviana Latif

Universitas Gadjah Mada,

Vocational School,

Department of Civil

Engineering,

Yogyakarta, Indonesia

\author{
Amalia Ula Hazhiyah \\ Universitas Gadjah Mada, \\ Vocational School, \\ Department of Civil \\ Engineering, \\ Yogyakarta, Indonesia
}

\author{
Adhitya Yoga Purnama \\ Universitas Gadjah Mada, \\ Vocational School, \\ Department of Civil \\ Engineering, \\ Yogyakarta, Indonesia
}

Key words: geoelectrical, soil layer, Wenner-Schlumberger configuration doi:10.5937/jaes0-29022

Cite article:

Latif Oktaviana D., Hazhiyah Ula A., Purnama Yoga A. (2021) APPLICATION OF GEOELECTRICAL METHODS FOR IDENTIFICATION OF SOIL LAYER, Journal of Applied Engineering Science, 19(4), 874 - 879, DOI:10.5937/ jaes0-29022

Online aceess of full paper is available at: www.engineeringscience.rs/browse-issues 


\title{
APPLICATION OF GEOELECTRICAL METHODS FOR IDENTIFICATION OF SOIL LAYER
}

\author{
Devi Oktaviana Latif*, Amalia Ula Hazhiyah, Adhitya Yoga Purnama \\ Universitas Gadjah Mada, Vocational School, Department of Civil Engineering, Yogyakarta, Indonesia
}

Landslide is a geological event caused by the movement of rock or land mass that can be defined as the displacement of slope-forming material, which is the original rock as well as the other material that is moving with the gravity. The factors that influence landslides are soil layer, slip surface and saturated soil. Mapping or determining the landslide area is done by identifying several parameters that can trigger landslide. The geophysical method that can be used to analyse soil layer is resistance type of geoelectrical. Variations of each rock or soil layer resistance below the measuring point can be obtained from the measurements of current and potential differences. The research site is located East Aceh district, Indonesia. Geoelectrical measurements using Wenner-Schlumberger electrode configuration. Based on geological information, field observation and geophysical measuring results, the area is dominated by clay, sand and gravel material. Lithology of clay dominates the underside of the surface (until the depth of \pm 30 meters. water that is held in sand lithology causes saturation of the sand. this is because there is a layer of clay under the sand which has low permeability or even impermeable properties. Saturated sand lithology can lead to contact between particles and has the potential to weaken it, causing soil movement

Key words: geoelectrical, soil layer, Wenner-Schlumberger configuration

\section{INTRODUCTION}

Landslide is a geological event caused by the movement of rock or land mass that can be defined as the displacement of slope-forming material, which is the original rock as well as the other material that is moving with the gravity $[1,13]$. Indonesian disaster Information Data (DIBI) in the official web of the National Disaster Management Agency (BNPB) recorded the incidence of landslides in Indonesia from 2010-2018 is 4366 cases. It ranks 3 after floods and tornadoes as the highest catastrophic figures for the last 10 years in Indonesia. Several impact caused by landslides are casualties (dies, injuries and lost), material loss, damage to the environment and public facilities also disrupting people's lives $[14,17]$.

Landslides can be caused by several reasons, including humans and nature. One of the nature factors that influence landslides are soil layer, slip surface and saturated soil. This slip surface is a water-resistant and slippery area which is generally consist of clay layer. In general, soil that has landslide will move according to the slip surface area. In general, to determine the sliding plane can be done by several methods such as soil investigation, drilling soil, soil samples, conduct tests in the laboratory and mapping layer of soil. however, the method of soil drilling, sampling and laboratory testing to determine the soil layer requires multiple borehole and requires a relatively longer time. so that we need a method that is relatively faster and cost effective for mapping the soil layers using geoelectric [5]. Mapping the landslide prone can be a preliminary step in the landslide mitigation.

Mapping or determining the landslide area is done by identifying several parameters that can trigger landslide, one of the parameters is the slip area analysis. Similar research was also conducted by Jongman and Garambois (2007) and Meric et all (2005) (using geophysical methods applied to subsurface landslide mapping. This geophysical method is used to determine the location of the vertical and lateral boundaries of the landslide debris, that is, the surface is rugged and detects water in the landslide debris. then this is supported by some researches $[2,8,9]$ show that the electrical method is one of the two most widely used methods of investigating this (the other is electromagnetic). The geophysical method can be used to analyse soil layer is geoelectrical resistivity and seismic. The geoelectrical method can be used to determine the electrical properties of the rock or soil layer by injecting electrodes into the ground. Potential difference is then measured and the results of current and potential differences can be known based on the type of each rock or soil layer below the measuring point. Furthermore, the depth of field slip discovered through analysis of resistivity value $[14,15]$. While the seismic method utilizes the transmission of seismic waves beneath the surface, which the speed of seismic wave can be analyzed to determine the thickness of the weathered rock or soil layer. this paper shows the method of geoelectrical testing and geoelectrical results of the soil layer located East Aceh, Indonesia. where this geoelectric result is an initial identification to determine the slip surface on the slope and is a data supplement for borehole.

\section{GEOELECTRICAL METHOD}

Geoelectrical method is one of the geophysical survey methods to identify the surface of the ground using the properties of rock electricity. The properties of the elec- 
tricity is the resistivity type. A resistivity geoelectrical survey is generally used for shallow exploration (approximately 500 meters below the surface). The basic principle of this method is to inject a high voltage electric current into the ground through two current electrodes. Furthermore, the potential difference is measured using two electrodes, then the transmitted current and difference of the measured potential can be known its resistivity value of existing rocks below the surface. Thus, resistivity value can be used as a reference to the type of rock below the surface. Geoelectrical surveys are describe into two, sounding and mapping. Sounding is a survey to identify changes in the rock resistivity to the vertical direction. This method of measurement is commonly called the VES (Vertical Electrical Sounding). The mapping method itself is the identification of changes of the surface rock resistivity to the lateral direction. The illustration of a potential equilibrium line that occurs due to a current injection is shown at two current points (A and $B$ current electrode) on the ground surface indicated by the fig 1 .

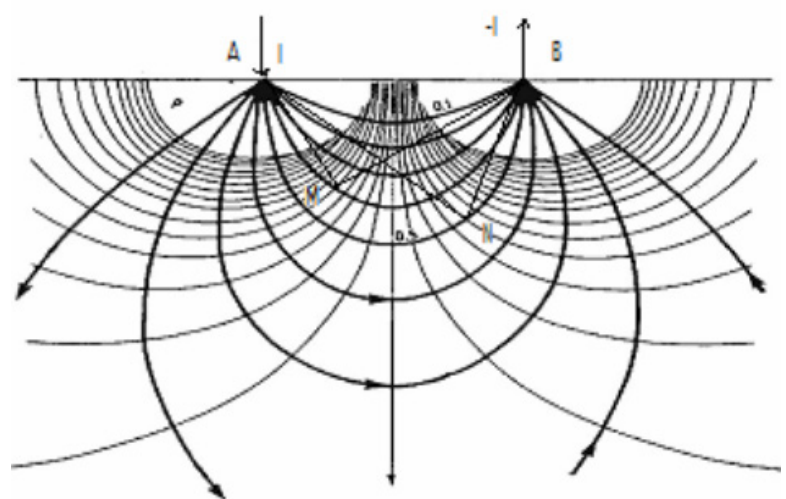

Figure 1: The pattern of the flow and the potential of an ECG between the two current electrodes and the opposite polarity (Bahri (2005) in Kanata, P. and Zubaidah, T. (2008))

The potential difference between the $\mathrm{M}$ and $\mathrm{N}$ potential electrodes caused by the current injection on the $A$ and $B$ electrodes is indicated by the following equation,

$\Delta V=V_{M}-V_{N}$

$\Delta V=\frac{1 \rho}{2 \pi}\left(\left(\frac{1}{A M}-\frac{1}{B M}\right)-\left(\frac{1}{A N}-\frac{1}{B N}\right)\right)$

$\rho=2 \pi \frac{\Delta V}{l}\left(\left(\frac{1}{A M}-\frac{1}{B M}\right)-\left(\frac{1}{A N}-\frac{1}{B N}\right)\right)^{-1}$

So,

$\rho=k \frac{\Delta V}{l}$

With I current in Amphere, $\Delta \mathrm{V}$ potential difference in volts, $\rho$ resistivity type in ohm meter and $\mathrm{K}$ as the geometry factor of the electrode in meters. So it gets,

$k=2 \pi\left(\left(\frac{1}{A M}-\frac{1}{B M}\right)-\left(\frac{1}{A N}-\frac{1}{B N}\right)\right)^{-1}$
This measurement used Wenner-Sclumberger electrode configuration. This configuration is a constant configuration with a space rule system which is where the $\mathrm{n}$ factor for this configuration is a comparison of the distances between the C1-P1 (or C2-P2) electrode with a space between P1 (Fig 2).

If the distance between the potential electrodes (P1 and $\mathrm{P} 2$ ) is a then the distance between the current electrode ( $\mathrm{C} 1$ and $\mathrm{C} 2$ ) is $2 n+A$. The resistivity determination process uses 4 electrodes placed in a straight line. Telford, W.M. et al. (1990) and Reynold (1997) in Sugito et al. (2010) provides the resistivity value of different types of rocks and water as seen in Table 1.

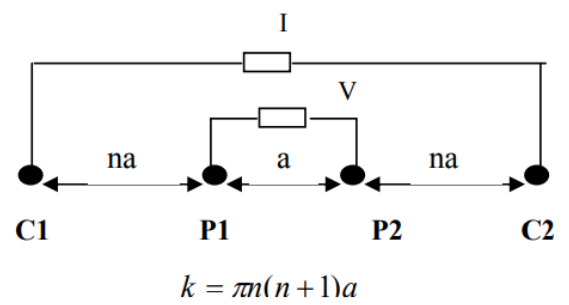

Figure 2: The electrode arrangement of the Wenner-Schlumberger configuration

Table 1: Resistivity value of different types of rocks and water

\begin{tabular}{|c|c|c|c|}
\hline Rock & $\begin{array}{c}\text { Resistivity } \\
\text { (Ohmme- } \\
\text { ter) }\end{array}$ & Water & $\begin{array}{c}\text { Resistivity } \\
\text { (Ohmme- } \\
\text { ter) }\end{array}$ \\
\hline $\begin{array}{c}\text { Soil Cov- } \\
\text { ered }\end{array}$ & $250-1700$ & $\begin{array}{c}\text { Meteoric } \\
\text { water }\end{array}$ & $30-1000$ \\
\hline Sandy Clay & $30-215$ & Sea Water & 0,2 \\
\hline Clay (Wet) & $1-100$ & $\begin{array}{c}\text { Saline wa- } \\
\text { ter 3\% }\end{array}$ & 0,15 \\
\hline Sand (dry) & $80-1050$ & $\begin{array}{c}\text { Saline wa- } \\
\text { ter 20\% }\end{array}$ & 0,05 \\
\hline $\begin{array}{c}\text { Soil (40\% } \\
\text { clay) }\end{array}$ & 8 & $\begin{array}{c}\text { Surface } \\
\text { Water } \\
\text { (lgneous } \\
\text { Rock) }\end{array}$ & $0,1-3000$ \\
\hline $\begin{array}{c}\text { Soil (20\% } \\
\text { clay) }\end{array}$ & 33 & $\begin{array}{c}\text { Surface } \\
\text { Water (Sed- } \\
\text { imentary } \\
\text { Rock) }\end{array}$ & $10-100$ \\
\hline $\begin{array}{c}\text { Clay (dry) } \\
\text { Tufaan } \\
\text { sand }\end{array}$ & $50-150$ & $\begin{array}{c}\text { Ground Wa- } \\
\text { ter (igneous } \\
\text { Rock) }\end{array}$ & $0,5-150$ \\
\hline & $\begin{array}{c}\text { Ground } \\
\text { Water (Sed- } \\
\text { imentary } \\
\text { Rock) }\end{array}$ & $1-100$ \\
\hline
\end{tabular}

\section{RESEARCH METHODS}

The research site is located in three sub-districts, Julok sub-district, Indra Makmu sub-district, and Nurussalam 


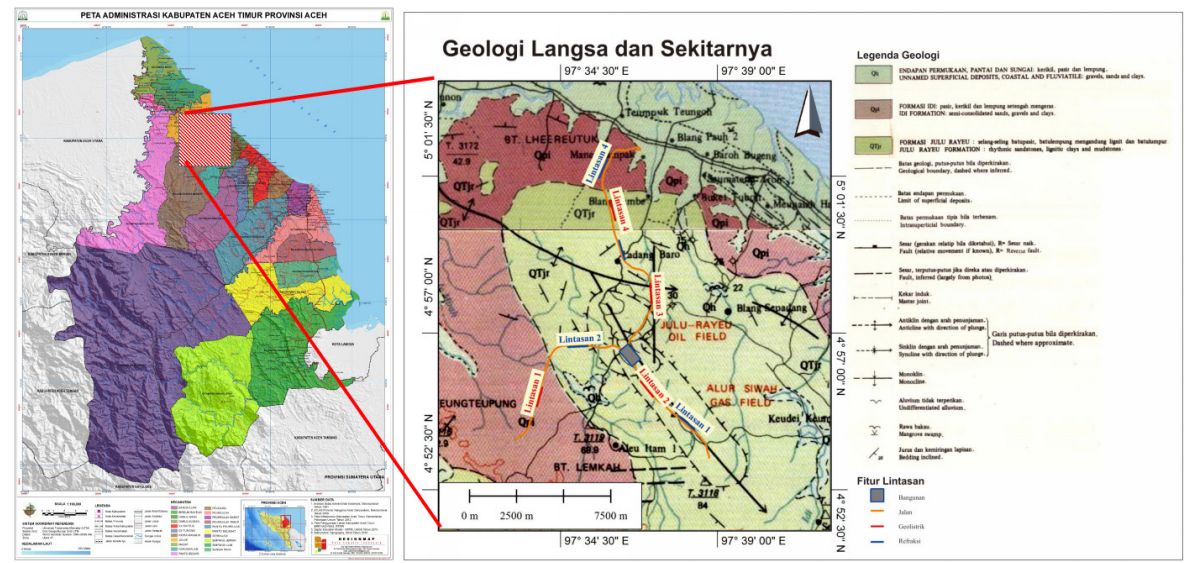

Figure 3: Research location map

sub-district where all three are located in East Aceh district. Research location shown in the Fig 3.

According to Cameron, N.R. (1980) [2] The island of Sumatra suffered a clockwise rotation at the end of the Miocene which resulted in the direction of the geological structure being southwest-northeast on the Plio-Pleistocene. The rotation and changing direction of this structure occurs due to fault of the Indian Ocean Plate to the west of Sumatra. The West also resulted in the western part of the island being lifted, and the eastern side became more down. The decline of the eastern part resulted in the land of erosion in the west to the east and resulted in the eastern part having a vast area of clay, peaty and mangroves. In the early Miocene period, Transgressi caused the East Aceh region to be flooded and resulted in sedimentation and forming the formation of Peutu, Belumai and Baong. Later in the late Miocene to the Pleistocene there was a regression that resulted in the stopping of the sea sedimentation and the clastic sedimentation resulting in the Keutapang, Seurula and Julu Rayeu formations.

Site investigation is carried out before starting the geoelectrical work. The acquisitions is done for 4 days. The Total trajectory was 4 with a breakdown of 1-round 1150 $\mathrm{m}$, the track 2 along $975 \mathrm{~m}$, trajectory 3 and 4 along $1150 \mathrm{~m}$. This geoelectrical acquisition uses the Wenner-Schlumberger configuration (Fig 2) which is a con- figuration with a system of space rules that Constant. Based on the fig 2, if the distance between the potential electrode (P1 and $\mathrm{P} 2)$ is a then the distance between the current electrode $(\mathrm{C} 1$ and $\mathrm{C} 2)$ is $2 \mathrm{na}+\mathrm{A}$.

\section{ANALYSIS AND RESULT}

\section{Geoelectrical Data Analysis}

Data of measurement results in the form of $V$ values (electrical voltage), I (electric current), and K (calculated from the position of the electrode). The next is done counting $\rho$ (pseudo resistivity) values by using formulas RhoApp=V.K/I in the spreadsheet. Followed by compiling data in the format required ZondRes2D software is in the format * dat.

The data that has been compiled in the format of DAT in software ZondRes2D then set into mesh parameters and the initiations model. The initial model or model created is a homogeneous subsurface model. With a homogeneous model then the mathematical model or the resulting response data will have a different value with the data response result of the measurement.

To get a data response (calculated data) that has the same value as measured data (measured data), it needs to be done inversion. Below we show examples of the results of the inversion of geoelectrical data (Fig 4 and Fig 5).
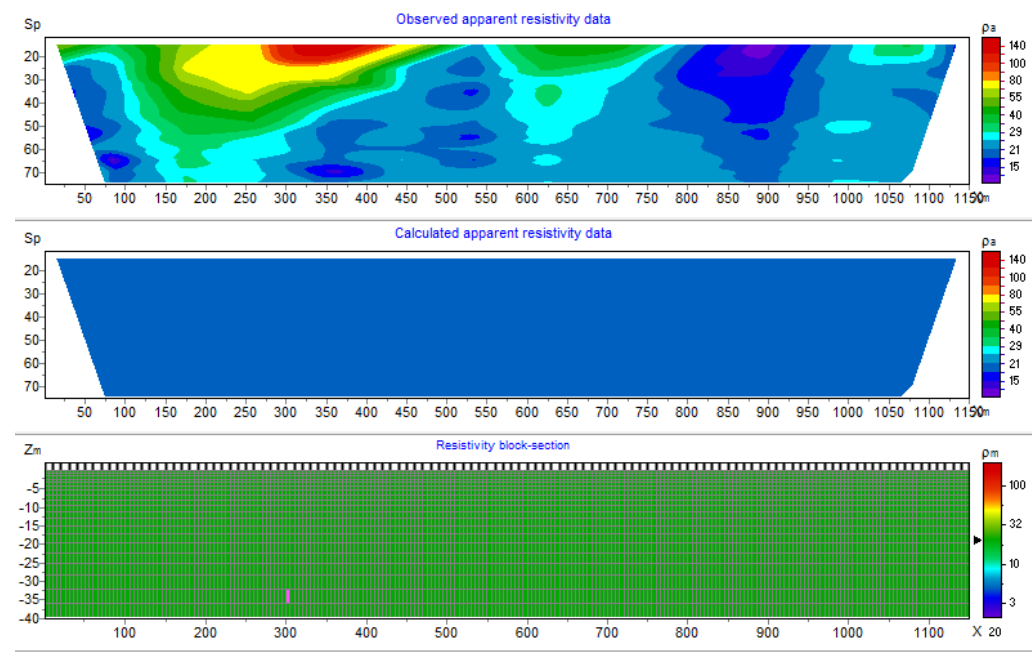

Figure 4: Measured Data 

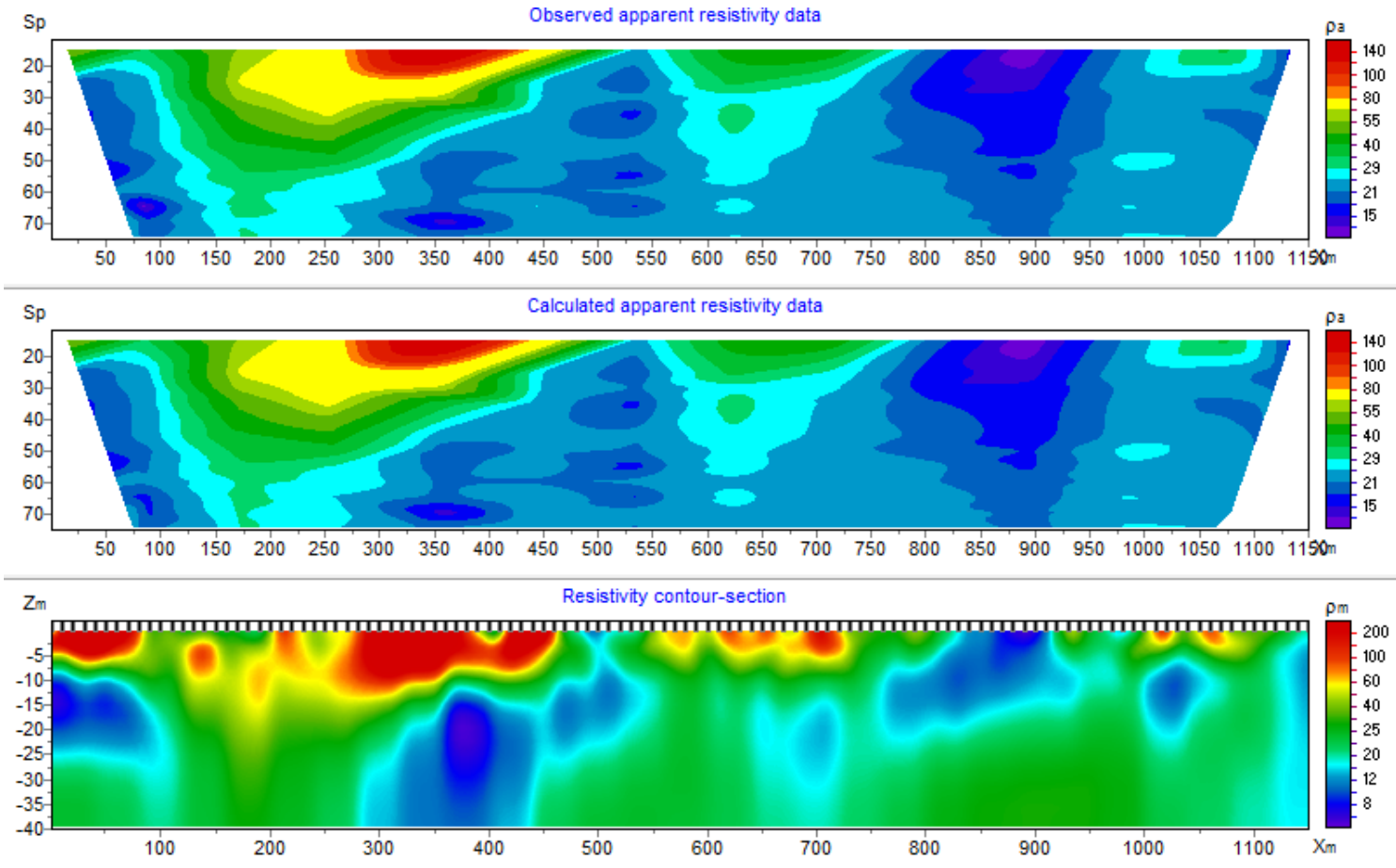

Figure 5: Measured and Calculated Data

\section{Geoelectrical Result}

From data that has been processed using ZondRes2D software, resistivity model is obtained as shown in Fig 6. The four trails above generally have a range of resistivity values from 1-250 ohm meters. On the 1 and 2 paths have a variation distribution of relatively similar resistivity values. As for the track 3 is dominated by the low resistivity value (blue color), the low resistivity value has a range of 1-10 ohm meters. Contrary to track 3 , track 4 is dominated by high resistivity (red color), low resistivity value has a range of 50-250 ohm meter.
From geological information and acquired resistivity model can be interpreted that low resistivity value associated with the clay present in this area and the high resistivity value of the gravel association which is widely found. The Medium value range (color green) with a range of 10-50 ohm meters is possible associated with a water-saturated pebble and gravel contact with a clay. Thus, the undersurface lithology of the geoelectrical measuring track can be modeled like Fig 7.

The sand or gravel on the clay prevent water coming from the surface. While the clay has a low permeability properties or even impermeable so that the water unable to soak

(a)

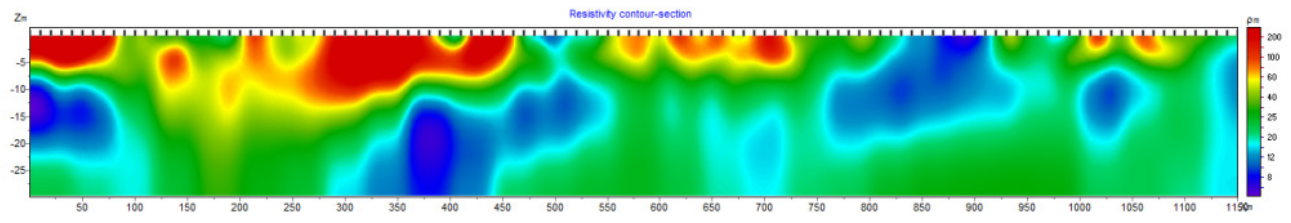

(b)



(c)



(d)

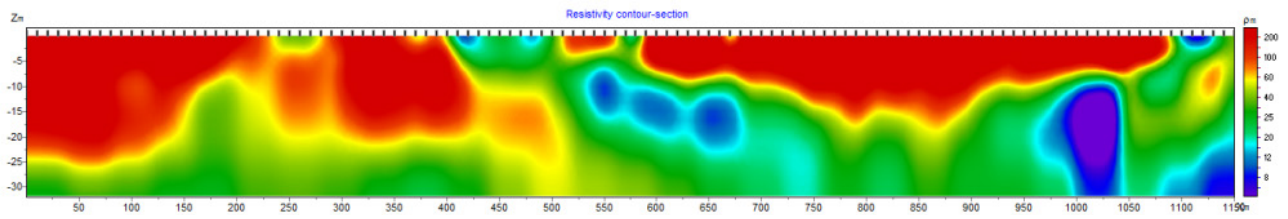

Figure 6: Subsurface resistivity Model (a) path 1, (b) path 2, (c) path 3, and (d) path 4 
(a)

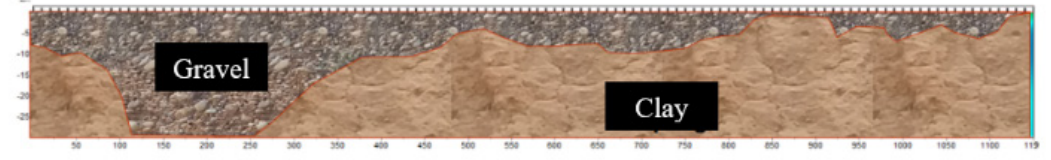

(b)

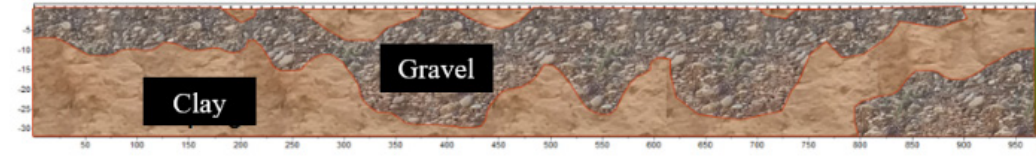

(c)

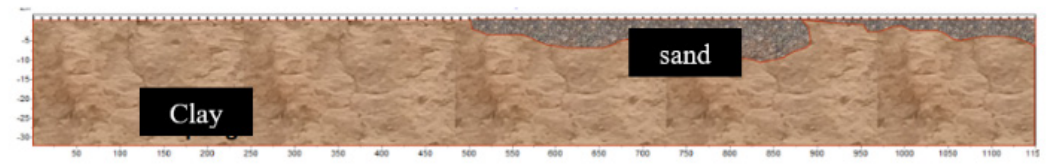

(d)

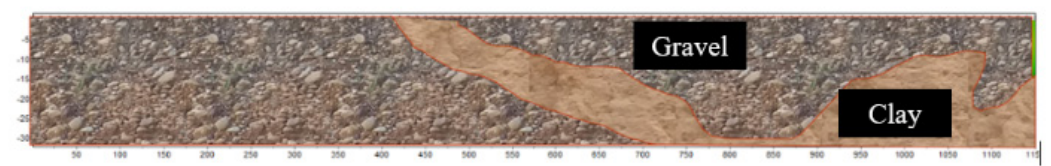

Figure 7: Subsurface lithology Model for (a) path 1, (b) path 2, (c) path 3, and (d) path 4

through its pores. This condition can cause the sand layer above the clay to experience high saturation of water. This high saturation condition can result in a weak contact between the sand particles. When the contact or the connective power between sand particles or gravel is weak, the area of slope will easily occur soil movement.

\section{CONCLUSION}

Based on geological information, field observation and geophysical measuring results, the area is dominated by clay, sand and gravel material. Lithology of clay dominates the underside of the surface (until the depth of \pm 30 meters). water that is held in sand lithology causes saturation of the sand. this is because there is a layer of clay under the sand which has low permeability or even impermeable properties. Saturated sand lithology can lead to contact between particles and has the potential to weaken it, causing soil movement.

\section{REFERENCES}

1. Arbanas, Z., Dugonjic, S., Vivoda, M. \& Jogodnik, V., 2011, Landslide Affected with An Open Pit Excavation in Flysch Deposit, Proceedings of the 15th European Conference on Soil Mechanics and Geotechnical Engineering, pp. 1319-1324

2. Bruno, F. and Marillier, F., 2000, Test of high-resolution seismic reflection and other geophysical techniques on the Boup Landslide in the Swiss Alps, Survey Geophysical, Vol. 21, pp 333-348, DOI: 10.1023/A:1006736824075

3. Cameron, N.R., Clarke, M.C.G., Aldiss, D.F., Aspden, J.A., \& Djunuddin, A., 1980, The geological evolution of northern Sumatra, Indonesian Petroleum Association, Proceedings 9th annual convention, Jakarta, pp 149-187
4. Cameron, N.R., Keats, W., Djuniddin, A., Ghazali, S.A., Harahap, H., Kartawa, W., Ngabito, H., Rock, N.M.S., Thompson, S.J., \& Whandoyo, R., 1981, Map of Lhokseumawe Geology, Sumatra, Center for Geological Research and development, Bandung.

5. Joab, M.J., and Andrew, M., 2009, Investigating Slope Failures Using Electrical Resistivity: Case Studies, The Journal of the Association of Professional Engineers of Trinidad and Tobag, Vol 38 No 1, pp 66-75, DOI: 10.11113/jt.v78.8568

6. Jongman, D. and Garambois, S., 2007, "Geophysical investigation of landslides: a review”, Bull. Soc. géol. Fr. Vol. 178, No. 2, pp. 101-112, DOI: 10.2113/gssgfbull. 178.2.101

7. Kanata, P and Zubaidah, T., 2008, Aplikasi Metode Geolistrik Tahanan Jenis Konfigurasi Wenner-Schlumberger untuk Survey Pipa Bawah Permukaan, Teknologi Elektro, Vol 7 No 2, 84-91.

8. Lapenna, V., Lorenzo, P., Perrone, A., Piscitelli, S., Rizzo, E. and Sdao, F., 2005, "2D electrical resistivity imaging of some complex landslides in Lucanian Apennine Chain, Southern Italy", Geophysics, No.70, B11 - B18, . DOI: 10.1190/1.1926571

9. Lebourg, T., Binet, S., Tric, E., Jomard, H. and El Bedoui, S., 2005, Geophysical survey to estimate the 3D sliding surface and the 4D evolution of the water pressure on part of a deep-seated landslid", Terra Nova, Vol.17, pp 399-406, DOI: 10.1111/j.13653121.2005.00623.x

10. Lowrie, W., 2007, Fundamentals of Geophysics, Cambridge University Press, Cambridge. 
11. Méric, O., Garambois, S., Jongman, D., Wathelet, M., Chatelain, J.-L. and Vengeon J.-M., 2005, Application of Geophysical methods for the Investigation of the Large Gravitational Mass Movement of Sechilienne, France, Canadian Geotechnical Journal, Vol.42, pp 1105-1115, DOI: 10.1139/T05-034

12. Paulin, G.L., Bursik, M., Ramirez-Herrera, M.T., Lugo-Hubp, J., Orozco, J.J.Z. \& Ayala, A.I., 2013, Landslide Inventory and Subceptibility Mapping in the Rio Chiquita-Barranca Del Muerto Watershed, Pico de Orizaba Volcano, Mexico, Springer-Verlag, Berlin Heidelberg, pp. 280-296, DOI: 10.1007/978-3-64222087-6_19.

13. Sassa, K., 2013, International Programme On Landslides, Springer-Verlag, Berlin Heidelberg, pp. 15-28,

14. Souisa, M., Hendrajaya L., and Handayani G, 2016, Landslide Dynamics and Determination Critical Condition Using of Resistivity Method in Desa Negeri Lima Ambon, Indonesian Journal of Physics, Vol.26, No.1, pp 1-4.
15. Souisa M., Hendrajaya, L. and Handayani, G., 2015, Determination of Landslide Slip Surface Using Geoelectrical Resistivity Method at Ambon City Moluccas Indonesia, Internasional Journal, IJETAE, Vol.5, Issue 7, 42-47, 2015

16. Telford, W. M., Geldart, L. P., \& Sheriff, R. E., 1990, Applied Geophysics. Cambridge University Press, DOI : 10.1017/CBO9781139167932

17. Varnes, D.J. \& IAEG, 1984, Commission on Landslides and other Mass-Movements: Landslide Hazard Zonation: A Review of Principles and Practice, UNESCO Press, Paris, p. 9. 